\title{
Realiasasi Spirit Entreprenuership melalui Website Berbasis E-Commerce di kalangan Mahasiswa \\ (Studi Pada Mahasiswa Jurusan Syariah dan Ekonomi Islam IAIN Kudus)
}

\author{
Oleh \\ Farida Rohmah \\ Institut Agama Islam Negeri Kudus \\ (riddafarida14@gmail.com)
}

\begin{abstract}
This research is motivated by the increasing number of unemployed college graduates, because more of them want to become office employees or state employees. In fact, there are opportunities that can be made to become new fields of work. Their mindset must be changed so that they do not become government spending to create jobs. Therefore, from now on it is necessary to introduce entrepreneurial education, so that their entrepreneurial spirit develops well. One of the objectives of giving this course is the formation of an entrepreneurial spirit. The purpose of this study is from a course program that can provide knowledge for college graduates about the world of business, and form a mindset to seriously become entrepreneurs. This research is descriptive qualitative and provides a real picture related to the competency of entrepreneurship courses in IAIN Kudus for students and the effect of the realization of Ecommerce utilization on student activities in becoming young entrepreneurs. E-commerce is the process of buying and selling transactions that use electronic devices such as telephone and internet. E-commerce is more than just buying and selling products online but includes all the processes of developing, marketing, selling, shipping, servicing and paying for customers and customers, with support from business partners around the world. This system relies heavily on internet resources and other technologies that can support this process. These results can be developed along with the level of need, because entrepreneurial subjects will increase along with the business world. the increasing competency in improving the spirit of young entrepreneurs is expected in the micro scope to increase the entrepreneur's bargaining position and in the macro scope to be able to economy development.
\end{abstract}

\section{Keyword: Entrepreneur, E-Commerce, Entreprenuership}

\section{A. PENDAHULUAN}

Ada beberapa cita-cita bangsa yang tertuang didalam Pembukaan Undang-Undang Dasar 1945 yaitu mewujudkan masyarakat Indonesia yang adil dan makmur. Untuk mewujudkan cita-cita tersebut Presiden Joko Widodo mencanangkan Sembilan agenda yang menjadi prioritas yang di sebut Nawacita. Salah satu Nawacita tersebut adalah mewujudkan kemandirian ekonomi bangsa serta meningkatkan produktivitas dan daya saing di pasar internasional.

Peran kewirausahaan adalah peran yang sangat stategis untuk mendukung agenda dari Nawacita demi kesejateraan bangsa. Semakin banyak wirausahawan baru, maka semmakin banyak pula akan tercipta lapangan kerja. Dengan terserapnya tenaga kerja maka produktivitas akan meningkat. Meningkatnya kewirausahaan maka akan menciptakan inovasi teknologi, produk maupun jasa baru yang dapat berdaya saing Indonesia dalam kompetisi di pasar global. Meningkatnya produktivitas akan didukung dengan penguatan daya saing sehingga akan meningkatkan pertumbuhan ekonomi secara nasional. Pertumbuhan ekonomi yang meningkat menjadi salah satu factor dalam kemakmuran suatu negara, hal ini juga diikuti dengan perkembangan kualitas maupun kuantitas wirausaha pada suatu negara mampu mendorong tercapainya kemakmuran suatu negara. 
Peran kewirausahaan untuk mewujudkan kemakmuran negara telah terbukti oleh negara maju yang kini tengah memimpin perekonomian global. Singapura misalnya, jumlah wirausahanya sebesar 7,2\%; sementara itu Jepang sebesar $11 \%$ serta negara adikuasa seperti Amerika Serikat memiliki jumlah wirausaha sebesar 11,5\% dari jumlah populasi penduduknya (Berita Sore, 25 November 2016). Jika membandingkan dengan negara-negara tersebut jumlah wirausaha di Indonesia masih tertinggal, bahkan jumlah wirausaha di Indonesia di bawah kriteria minimal yang dipaparkan oleh David McClelland. Rendahnya jumlah wirausaha di Indonesia mengaggambarkan bahwa semangat dan jiwa kewirausahaan belum menjadi budaya pada sebagian besar masyarakat Indonesia, sehingga jumlah masyarakat yang memutuskan untuk berwirausaha relatif rendah.

Hal ini di buktikan dari hasil Susenas BPS bulan Maret 2006 menemukan adanya penduduk miskin di Indonesia sebesar $17,75 \%$ dari total 222 juta penduduk. Sementara itu tercatat ada $10,8 \%$ - $11 \%$ dari jumlah penduduk di Indonesia sebagai pengangguran terbuka. Diperkirakan jumlah pengangguran akan meningkat drastic karena aktivitas sektor riil dunia bisnis menunjukkan stagnansi. Keadaan tersebut akan berdampak negatif terhadap stabilitas sosial dan kemasyarakatan (www.kelembagaan.dikti.go.id, 2009).

Ternyata peran kewirausahaan yang begitu penting dalam mendukung agenda peran nasional Nawacita maka pemerintah telah memberikan langkah-langkah strategis untuk mendukung pembangunan kewirausahaan di Indonesia. Berdasarkan Renstra Deputi Bidang Ekonomi Kreatif, Kewirausahaan dan KUKM 2015-2019 langkah dasar yang diambil pemerintah untuk mendukung pengembangan kualitas maupun kuantitas wirausaha adalah dengan melakukan pembibitan wirausaha baru melalui jalur pendidikan. Langkah ini dilakukan dengan tujuan untuk membangkitkan semangat dan jiwa kewirausahaan sekaligus untuk memberi bekali keterampilan dalam menjadi wirausaha untuk generasi muda dengan tujuan jumlah wirausaha di Indonesia dapat meningkat.

Pembentukan jiwa kewirausahaan baru dapat melalui jalur pendidikan dimulai dari sejak tahun 1995 melalui Instruksi Presiden Soeharto tentang gerakan nasional memasyarakatkan dan membudayakan kewirausahaan. Semenjak saat itu berbagai program kewirausahaan mulai diterapkan oleh berbagai lembaga pendidikan di Indonesia termasuk Lembaga Pendidikan Tinggi. Program kewirausahaan di perguruan tinggi bahkan telah difasilitasi oleh Dikti sejak tahun 1997 dengan menyelenggarakan berbagai program pendidikan kewirausahaan yang meliputi Kuliah Kewirausahaan (KWU), Magang Kewirausahaan (MKU), Kuliah Kerja Usaha (KKU), Konsultasi Bisnis dan Penempatan Kerja (KBPK), serta Inkubator Wirausaha Baru (INWUB) (Susilaningsih, 2015: 850). Selanjutnya, program-program tersebut sampai saat ini terus mengalami perbaikan dan penyesuaian dalam rangka mencetak lulusan perguruan tinggi yang memiliki semangat dan jiwa kewirausahaan serta memiliki keterampilan berwirausaha.

Lulusan yang dibekali semangat dan jiwa kewirausahaan serta kemampuan berwirausaha diharapkan memiliki keinginan yang kuat disertai usaha keras untuk menciptakan lapangan pekerjaannya sendiri melalui kegiatan kewirausahaan. Penciptaan lapangan pekerjaan secara mandiri oleh masyarakat akan mengurangi beban pemerintah dalam menyediakan lapangan pekerjaan sehingga kesempatan kerja dapat terbuka lebih lebar dan angka pengangguran dapat berkurang. Namun data dari Badan Pusat Statistika menunjukkan bahwa angka pengangguran dari lulusan perguruan tinggi di Indonesia dalam kurun waktu tiga tahun terakhir justru mengalami peningkatan, terutama pada lulusan universitas. 


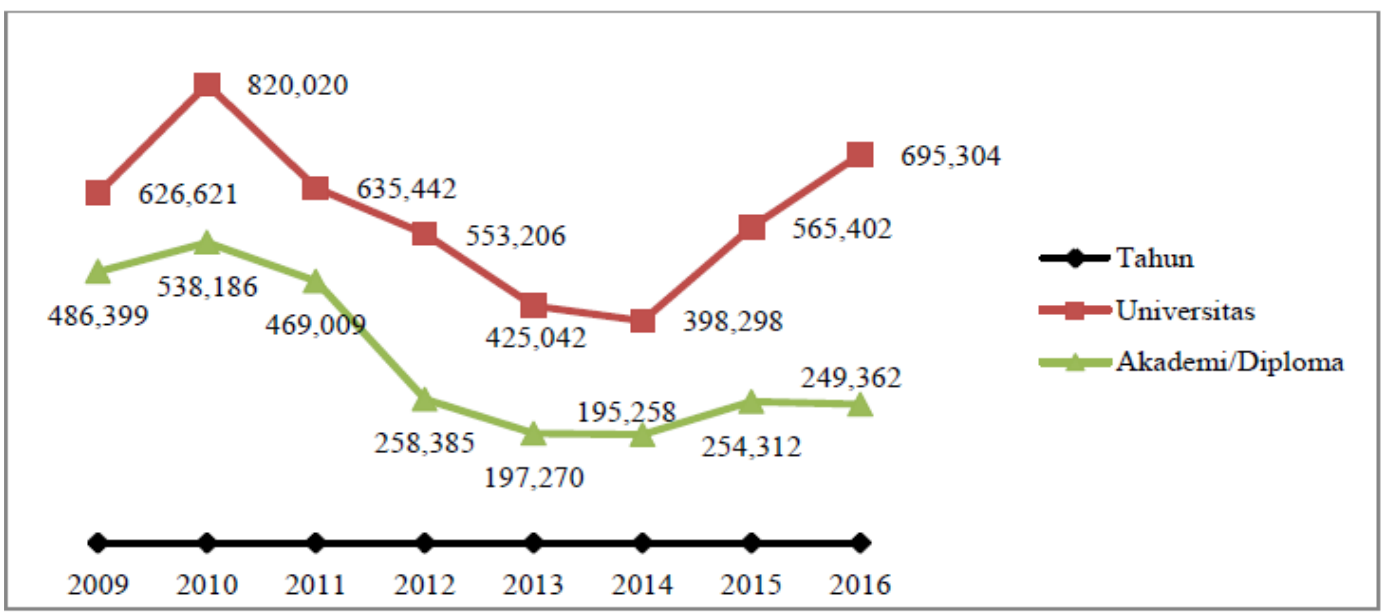

Sumber: https://www.bps.go.id/

Berdasarkan Gambar 1. jumlah pengangguran lulusan perguruan tinggi atau disebut juga sebagai pengangguran terdidik dari tahun 2014 mengalami trend yang terus meningkat. Bahkan jika diliha peningkatan pengangguran terdidik pada lulusan universitas menunjukkan kenaikan yang cukup tinggi, dimana dari tahun 2014 ke tahun 2016 persentase kenaikannya mencapai $74,57 \%$. Kenaikan angka pengangguran terdidik pada lulusan universitas disebabkan oleh terbatasannya lapangan pekerjaan yang tersedia yang diakibatkan melemahnya lapangan pekerjaan baru.

Namun kenyataan yang terjadi yang menunjukkan bahwa lulusan perguruan tinggi bukan pencipta lapangan pekerjaan, akan tetapi sebagai pencari kerja (job seeker). Hal ini karena pembelajaran di perguruan tinggi fokus pada bagaimana menyiapkan mahasiswa yang cepat lulus dan mendapatkan pekerjaan, namun bukan lulusan yang siap menciptakan pekerjaan (www.kelembagaan.dikti.go.id, 2009). Sementara itu, efektivitas kewirausahaan masih relatif rendah. Kewirausahaan merupakan semangat, sikap, perilaku kemampuan seseorang dalam menangani usaha dan atau kegiatan yang mengarah pada upaya mencari, menciptakan, menerapkan cara kerja, teknologi dan produk baru dengan meningkatkan efisiensi dalam rangka memberikan pelayanan yang lebih baik dan atau memperoleh keuntungan yang lebih besar (www.kelembagaan.dikti.go.id, 2009). Kewirausahaan memerlukan softskill. Karena itu mahasiswa diarahkan untuk memiliki softskill tersebut.

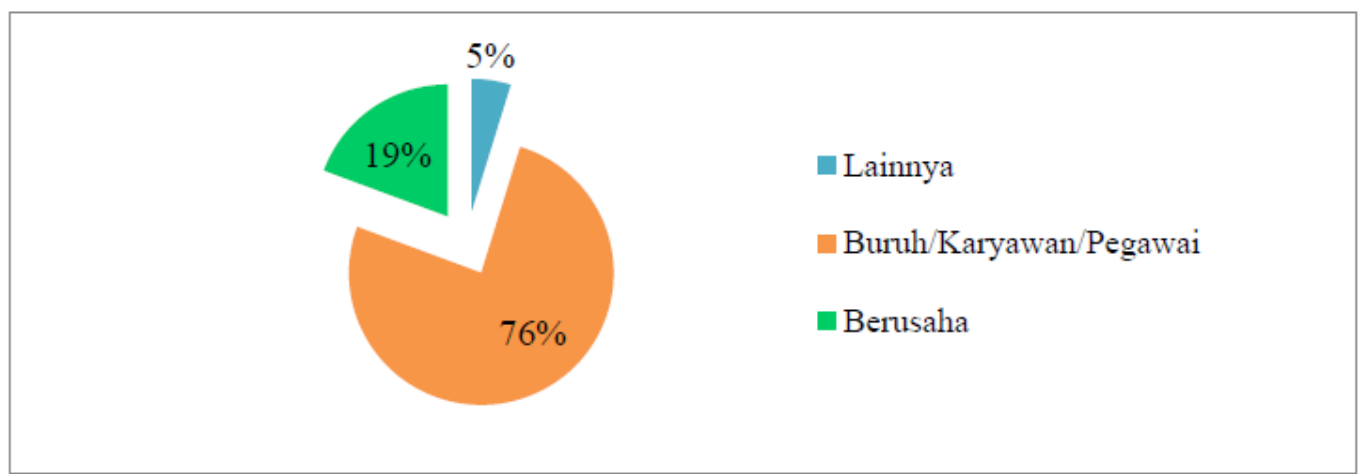

Sumber: https://www.bps.go.id/

Gambar 2. Persentase Status Pekerjaan Utama Lulusan Universitas Pada Tahun 2016 di Indonesia menunjukkan bahwa mayoritas lulusan universitas bekerja sebagai buruh/karyawan/pegawai, sehingga dapat dikatakan bahwa sebagian besar lulusan universitas masih berorientasi sebagai job seeker dimana mereka cenderung bekerja pada pekerjaan yang diciptakan oleh orang lain. Mindset inilah yang menyebabkan rendahnya jumlah wirausaha di Indonesia yang berdampak pada rendahnya penciptaan lapangan 
pekerjaan baru melalui kegiatan berwirausaha sehingga angka pengangguran terdidik di Indonesia terus meningkat.

Minimnya jumlah wirausaha dan meningkatnya angka pengangguran terdidik di Indonesia terutama pada lulusan universitas menunjukkan bahwa berbagai program pembelajaran kewirausahaan di universitas yang sudah dikembangkan selama dua dekade belum mampu memacu semangat dan jiwa kewirausahaan mahasiswa sehingga keinginan berwirausaha mahasiswa relatif rendah. Oleh karena itu sampai saat ini pemerintah terus mendorong berbagai universitas di Indonesia untuk berlomba-lomba mencari skema pembelajaran kewirausahaan yang paling baik yang tidak hanya memberikan keterampilan berwirausaha, tetapi juga dapat meningkatkan semangat dan jiwa kewirausahaan mahasiswa serta dapat mengubah pola pikir mahasiswa yang masih berorientasi sebagai job seeker menjadi job creator.

Di sisi lain saat ini mahasiswa yang lulus diharapkan memiliki kompetensi sesuai dengan bidang pendidikan yang ditempuhnya sehingga lebih mampu bersaing dalam mendapatkan pekerjaan. Sementara jumlah lapangan kerja semakin terbatas sehingga sudah semestinya merubah paradigma agar mahasiswa tidak hanya mencari pekerjaan tetapi juga harus dapat menciptakan pekerjaan melalui pendidikannya. Mahasiswa yang lulus nantinya lebih siap berwirausaha dan tidak hanya menitik beratkan menjadi karyawan atau pegawai pemerintah.

Peran entrepreneur dalam menentukan kemajuan suatu negara telah dibuktikan oleh beberapa negara maju, seperti Amerika Serikat, Jepang, plus tetangga terdekat kita, yaitu Singapura dan Malaysia. Di Amerika Serikat, sampai saat ini, sudah lebih dari 12 persen penduduknya menjadi entrepreneur, dan dalam setiap 11 detik lahir entrepreneur baru, serta data menunjukkan bahwa 1 dari 12 orang Amerika Serikat terlibat langsung dalam kegiatan entrepreneur. Itulah yang menjadikan Amerika Serikat sebagai negara adi kuasa dan super power (Mindagi 2014).

Menurut Suryana (2003), kewirausahaan memiliki hahekat penting sebagai berikut: (1) Kewirausahaan adalah suatu nilai yang diwujudkan dalam perilaku yang dijadikan dasar sumber daya, tenaga penggerak, tujuan, siasat, kiat, proses, dan hasil bisnis. (2) Kewirausahaan adalah suatu kemampuan untuk menciptakan sesuatu yang baru dan berbeda (ability to create the new and different). (3) Kewirausahaan adalah suatu proses penerapan kreativitas dan inovasi dalam memecahkan persoalan dan menemukan peluang untuk memperbaiki kehidupan. (4) Kewirausahaan adalah suatu nilai yang diperlukan untuk memulai suatu usaha (start-up phase) dan perkembangan usaha (venture growth), (5)

Mandagi mengatakan dalam penelitiannya (2014), perguruan tinggi berperan penting dalam menciptakan mahasiswa kreatif dalam berwirausaha karena Perguruan Tinggi sebagai salah satu pusat pembinaan dan pengembangan kewirausahaan. Ditetapkan melalui hasil pertemuan Kerjasama Ekonomi wilayah Asia dan Pasifik atau APEC (Asia-Pacific Economic Cooperation) di Seatle, Amerika Serikat, yang salah satu agenda kesepakatan adalah bahwa untuk membantu mempercepat pertumbuhan perekonomian di wilayah Asia dan Pasifik secara luas, perlu ada kerjasama "tripartite" antara "Government-BusinessUniversities'

Hal ini merupakan investasi modal manusia untuk mempersiapkan para mahasiswa dalam memulai bisnis baru melalui integrasi pengalaman, keterampilan, dan pengetahuan penting untuk mengembangkan dan memperluas sebuah bisnis. Pendidikan kewirausahaan juga dapat meningkatkan minat para mahasiswa untuk memilih kewirausahaan sebagai salah satu pilihan karir selain pilihan karir menjadi pegawai swasta, PNS, atau pegawai BUMN di mana secara signifikan dapat mengarahkan sikap, perilaku, dan minat ke arah kewirausahaan 
Kewirausahaan merupakan semangat, sikap, perilaku kemampuan seseorang dalam menangani usaha dan atau kegiatan yang mengarah pada upaya mencari, menciptakan, menerapkan cara kerja, teknologi dan produk baru dengan meningkatkan efisiensi dalam rangkamemberikan pelayanan yang lebih baik dan atau memperoleh keuntungan yang lebih besar (www.kelembagaan.dikti.go.id, 2009). Kewirausahaan memerlukan softskill. Karena itu mahasiswa diarahkan untuk memiliki softskill tersebut. Pembentukan softskill wirausaha salah satunya adalah kemampuan untuk bertindak efisien dengan tidak melupakan penciptaan nilai tambah untuk kemakmuran. Usaha tersebut dapat dilakukan dengan berbagai metode dan salah satunya adalah teknologi informasi. Aplikasi teknologi di bidang bisnis berdampak luas seperti terbukanya supplier dan konsumen. Salah satu teknologi tersebut adalah e-commerce. Karena itu, pengembangan kewirausahaan perlu memperhatikan sisi intangible, yakni penguasaan softskill melalui adopsi $e$-commerce.

Institut Agama Islam Negeri Kudus (IAIN Kudus) sebagai lembaga pendidikan tinggi yang mengelola dua bidang keahlian, yaitu kependidikan dan nonkependidikan merupakan salah satu universitas yang memiliki komitmen tinggi dalam mendukung semangat dan jiwa kewirausahaan bagi mahasiswanya. Berbagai program pendidikan dan pembelajaran kewirausahaan di IAIN Kudus secara efektif sudah berjalan beberapa tahun, bahkan pembelajaran kewirausahaan melalui mata kuliah kewirausahaan di IAIN Kudus bersifat wajib bagi seluruh program studi. Pada pelaksanaannya pembelajaran kewirausahaan yang diselenggarakan oleh setiap program studi memiliki karakteristik yang berbeda-beda hal ini disesuaikan dengan kebutuhan dan kondisi program studi masing-masing. Kebijakan tersebut diambil dan diterapkan agar mahasiswa dari bidang keahlian kependidikan maupun nonkependidikan mampu keterampilan selain diluar bidang keahliannya sebagai bekal agar tidak bergantung pada lapangan pekerjaan yang diciptakan oleh orang lain, tetapi memiliki keinginan serta kemampuan menciptakan lapangan pekerjaannya sendiri.

Penelitian ini diharapkan akan mampu memberikan gambaran riil terkait kompetensi matakuliah kewirauasahan pada mahasiswa dan pengaruh realisasi pemanfaatan Ecommerce pada kegiatan mahasiswa dalam menjadi wirausahawan muda. Berdasarkan hasil penelitian tersebut diharapkan dapat diketahui potensi dan juga kelemahan yang dihadapi sehingga dapat dikembangkan model pelatihan kewirausahaan yang sesuai kebutuhan yang mampu meningkatkan kompetensi peningkatan dan perluasan pemasaran bagi pelaku wirausaha muda. Dengan meningkatnya kompetensi peningkatan jiwa wirausaha muda diharapkan dalam ruang lingkup mikro dapat meningkatkan bargaining position wirausahawan tersebut dan dalam ruang lingkup makro mampu mengembangkan perekonomian nasional.

\section{B. PEMBAHASAN}

\section{Landasan Teori}

\section{a. Kewirausahaan}

Istilah entrepreneur (wirausaha) berasal dari bahasa Perancis entreprende yang berarti berusaha atau mengusahakan. Sedangkan entrepreneur dalam bahasa Indonesia dapat diartikan wirausaha yang berasal dari kata 'wira', memiliki makna sebagai orang yang berani, teladan, utama, atau patut dicontoh, sedangkan usaha yang berarti kerja keras untuk memperoleh hasil atau menghasilkan sesuatu. Sehingga wirausaha adalah seseorang yang mempunyai kreativitas dan semangat yang tinggi untuk bekerja dan berhasil dalam usahanya.

Menurut Stoner (1995) ada empat keunggulan yang dimiliki kewirausahaan yaitu sebagai pendukung pertumbuhan ekonomi, meningkatkan produktivitas, menciptakan teknologi, produk dan jasa baru yang inovatif serta menciptakan perubahan dan kompetisi baru pada pasar (Leonardus, 2014: 45). 
Mc Clelland, (1961), Sengupta dan Debnath, (1994) membuktikan bahwa faktor kepribadian seperti kebutuhan akan prestasi dan efikasi diri merupakan prediktor signifikan intensi kewirausahaan. Hasil temuan Indarti dan Rostiani (2008) juga menyatakan bahwa semakin tinggi kepercayaan diri seorang mahasiswa atas kemampuan dirinya untuk dapat berusaha, maka semakin besar pula keinginannya untuk menjadi seorang wirausaha. Sinha (1996) menyebutkan bahwa faktor demografi seperti jenis kelamin, usia, latar belakang pendidikan dan pengalaman bekerja mempengaruhi intensi kewirausahaan. Penelitian Indarti dan Rostiani (2008) menemukan bahwa pengalaman bekerja mempengaruhi intensi kewirausahaan mahasiswa Norwegia. Mahasiswa dengan pengalaman bekerja sebelumnya memiliki intensi kewirausahaan yang lebih tinggi dibandingkan mereka yang belum pernah bekerja sebelumnya meskipun temuan ini tidak berlaku pada mahasiswa Jepang dan Indonesia, akan tetapi temuan ini sejalan dengan hasil penelitian Kolvereid (1996).

\section{b. E-commerce}

E-commerce adalah merujuk pada berbagai aktivitas bisnis yang berbasis elektronik, seperti order via elektronik, penggunaan email, penggunaan internet dan jasa online (Kotler, 2000). Periode awal adopsi e-commerce kebanyakan terjadi pada bidang hardware \& software komputer, buku, dan musik. Kemudian berkembang ke produk lain.

E-commerces adalah proses transaksi jual beli yang menggunakan alat elektronik aseperti telepon dan internet. E-commerce lebih dari sekedar membeli dan menjual produk secara online namun meliputi segenap proses dari pengembangan, pemasaran, penjualan, pengiriman, pelayanan dan pembayaran para konsumen maupun pelanggan, dengan dukungan dari mitra bisnis seluruh dunia. System ini sangat bergantung pada sumber daya internet dan teknologi lain yang dapat mendukung dari proses ini.

E-Commerce dapat membantu penjual dalam mempromosikan barang secra online karena ecommerce mampu memberikan kemudahanbagi calon konsumen untuk membeli dan mendapatkan barang sesuai dengan keinginan dan memanfaatkan semua fasilitas yang ada.

Selanjutnya e-commerce dapat didefinisikan dari beberapa perspektif:

1. Perspektif Komunikasi: e-commerce merupakan pengiriman informasi, produk/layanan, atau pembayaran melalui lini telepon, jaraingan computer atau sarana elektronik lainnya.

2. Perspektif proses Bisnis: E-commerce merupakan aplikasi teknologi menuju transaksi dan aliran kerja perusahaan.

3. Perspektif layanan: e-commerce merupakan salah satu alat untuk memenuhi keinginan perusahaan, konsumen dan manajemen dalam memangkas service cost ketika meningkatkan mutu barang dan kecepatan pelayanan.

4. Perspektif Online: e commerce berkaitan dengan kapasitas jual beli produk dan informasi di internet dan jasa online lainnya.

Sehingga e-commerce dapat menjadi fasilitator dalam prose bisnis yang dimulai dari pengembangan, pemasaran, penjualan, pengiriman, pelyanan dan pembayaran para pelanggan dengan pendukung dari mitra bisnis di seluruh dunia.

Kegiatan e- commerce mencakup banyak hal, untukj membedakan e-commerce dibedakan menjadi 2 berdasarkan karakteristiknya:

1. Bussiness to Business, karakteistiknya:

a. Pertukaran data dilakukkan secra berulang-ulang dan berkala dengan format data yang telah disepakati bersama

b. Salah satu pelaku tidak harus menunggu rekan mereka lainnya untuk mengirimkan data. 
c. Model yang umum digunakan peer to peer, dimana processing disistribusikan dikedua bisnis.

2. Business to consumer, karakteristiknya:

a. Servis yang digunakan berdasarkan permintaan

b. Sering dilakukan system pendekatan client-server

\section{c. Intensi Berwirausaha}

Intensi merupakan kunci utama untuk memprediksi perilaku manusia dan sebagai sebuah konstruk psikologis yang menunjukkan kekuatan motivasi seseorang dalam hal perencanaan yang sadar dalam usaha untuk menghasilkan perilaku yang dimaksud (Eagly \& Chaiken,1993). Berdasarkan pengertian tersebut dapat diambil kesimpulan bahwa kewirausahaan adalah orang yang menciptakan kerja bagi orang lain dengan cara mendirikan, mengembangkan, dan bersedia mengambil resiko pribadi dalam menemukan peluang berusaha dan secara kreatif menggunakan potensi-potensi dirinya untuk mengenali produk, mengelola dan menentukan cara produksi, menyusun operasi untuk pengadaan produk, memasarkannya serta mengatur permodalan operasinya. Sedangkan pengertian intensi adalah kesungguhan niat seseorang untuk melakukan perbuatan atau memunculkan suatu perilaku tertentu. Berdasarkan pendapat mengenai intensi dan wirausaha yang telah dikemukakan, maka intensi berwirausaha adalah keinginan atau niat yang ada pada diri seseorang untuk melakukan suatu tindakan wirausaha.

Hisrich \& peters (2013) mengemukakakan bahwa kewirausahaan berkaitan dengan suatu perilaku yang mencakup: (a) inisiatif (b) kemampuan untuk mengelola sumber daya, baik sumber daya manusia atu sumber daya alam dalam berbagai situasi untuk menciptakan keuntungan (c) berani mengambil resiko. Gray (Nababan, 2003) mentebutkan terdapat 20 ciri atau sifat umum seorang wirausaha, yaitu: Kemauan kuat untuk mencapai tujuan, kebutuhan untk bergaul erat dengan orang lain, kebutuhan untuk bergaul erat dengan karyawan, kemampuan untuk menerima ketidakpastian, kesehatan fisik yang baik, tingkat energi yang tinggi, kemampuan untuk menghadapi resiko, yakin pada diri sendiri, inovatif, kemampuan memimpin secara efektif, sabar, keinginan kuat memiliki uang, terorganisasi baik, keinginan untuk mencipta, kebutuhan kekuasaan, ketekunan, percaya diri, keinginan dan kemauan mengambil inisiatif, persaingan, kepandaian yang beragam. Menurut Katz dan Gartner (1988), intensi kewirausahaan dapat diartikan sebagai proses pencarian informasi yang dapat digunakan untuk mencapai tujuan pembentukan suatu usaha. Menurut Fishbein dan Ajzen (Wijaya, 2007), intensi merupakan komponen dalam diri individu yang mengacu pada keinginan untuk melakukan tingkah laku tertentu. Linan dalam penelitiannya (2004), menyebutkan intensi merupakan elemen yang fundamental yang dapat menjelaskan sebuah perilaku. Armitage dan Corner (1999) mengungkapkan bahwa sebagai prediktor perilaku, intensi dipandang sebagai motivasi yang sangat diperlukan ketika seseorang akan melakukan perilaku tertentu. Fishbein dan Ajzen menerangkan bahwa intensi merupakan prediktor sukses dari perilaku karena ia menjembatani sikap dan perilaku.

Salah satu model perkembangan niat yang dirumuskan oleh Ajzen yaitu Theory of Planned Behavior (TPB). TPB mengidentifikasikan tiga faktor yang mendahului niat. Dua faktor mencerminkan keinginan yang dirasakan untuk melakukan suatu perilaku yaitu: sikap pribadi (personal attitude) terhadap hasil perilaku dan norma-norma sosial (subjective norm) yang dirasakan. Faktor yang ketiga adalah kontrol perilaku yang dirasakan (perceived feasibility), mencerminkan persepsi bahwa perilaku dikontrol secara pribadi. Menurut Ajzen (2006), terbentuknya intensi dapat diterangkan dengan TPB yang mengasumsikan manusia selalu mempunyai tujuan dalam berperilaku. Teori ini 
menyebutkan bahwa intensi adalah fungsi dari tiga determinan dasar, yaitu: sikap berperilaku (attitude), norma subyektif (subjective norm), dan persepsi kontrol perilaku (perceived behavior control). Adapun penjelasannya adalah (1) Sikap berperilaku (attitude), yang merupakan dasar bagi pembentukan intensi. Sikap terhadap suatu perilaku dipengaruhi oleh keyakinan bahwa perilaku tersebut akan membawa hasil yang diinginkan atau tidak diinginkan.

Terdapat dua aspek pokok dalam sikap terhadap perilaku, yaitu: keyakinan individu bahwa menampilkan atau tidak menampilkan perilaku tertentu akan menghasilkan akibatakibat atau hasil-hasil tertentu, dan merupakan aspek pengetahuan individu tentang obyek sikap dapat pula berupa opini individu hal yang belum tentu sesuai dengan kenyataan. Semakin positif keyakinan individu akan akibat dari suatu obyek sikap, maka akan semakin positif pula sikap individu terhadap obyek sikap tersebut, demikian pula sebaliknya. (2) Norma subyektif (subjective norm) yaitu keyakinan individu akan norma, orang sekitarnya dan motivasi individu untuk mengikuti norma tersebut. Terdapat dua aspek pokok dalam norma subjektif, yaitu: keyakinan akan harapan-harapan norma referensi dan motivasi kesediaan individu untuk melaksanakan atau tidak melaksanakan pendapat atau pikiran pihak lain yang dianggap penting bahwa individu harus atau tidak harus berperilaku. (3) Persepsi kontrol perilaku (perceived Behavior Control), yang merupakan dasar bagi pembentukan kontrol perilaku yang dipersepsikan. Kontrol perilaku yang dipersepsikan merupakan persepsi terhadap kekuatan faktor-faktor yang mempermudah atau mempersulit suatu perilaku.

Friedman dan Shustack (2008) menjelaskan bahwa seseorang yang memiliki kebutuhan akan berprestasi mempunyai kecenderungan untuk tekun bahkan terdorong untuk memenuhi tugas yang diembankan pada dirinya. Indarti dan Rostiani, (2008) mengemukakan bahwa elemen kontekstual meliputi tiga faktor yang mempengaruhi wirausaha yaitu akses kepada modal, informasi dan kualitas jaringan sosial yang dimiliki, yang kemudian disebut kesiapan instrumen

\section{METODE PENELITIAN}

\section{Ruang Lingkup dan Objek Penelitian}

Ruang lingkup penelitian ini adalah di wilayah kabupaten Kudus. Sapling pada penelitian ini dilakukkan dengan purposive sampling dengan sasaran responden yang memenuhi kreteria tertentu dalam mencapai tujuan. Dalam penelitian ini sampel nya adalah mahasiswa pelaku entrepreneur di jurusan Syariah dan Ekonomi Islam yang telah menempuh matakuliah kewirausahaan dan masih menjalankan usaha di berbagai sector ekonomi. Sampel penelitian ini terdiri dari 168 pelaku wirausahawan muda.

\section{Jenis Data dan Metode Pengumpulan Data}

Dalam penlitian ini menggunakan diskriptif kuantitatif, yaitu salah satu jenis penelitian yang menyajikan gambaran secara lengkap mengenai objek penelitian. Data yang digunakan adalah data primer. Data primer diperoleh melalui angket secara online yang disebarkan kepada mahasiswa IAIN Kudus yang telah mendapatkan matakuliah kewirausahaan.

\section{HASIL PENELITIAN}

\section{Data Deskriptif Lapangan}

E-commerce didefinisikan sebagai proses pembelian, penjualan, mentransfer atau bertukar produk, jasa atau informasi melalui jaringan komputer melalui internet (Kozinets et al., 2010). Dengan mengambil bentuk-bentuk tradisional dari proses bisnis dan memanfaatkan jejaring sosial melalui internet, strategi bisnis dapat berhasil jika dilakukan dengan benar, yang akhirnya menghasilkan peningkatan pelanggan, kesadaran merk dan 
pendapatan. Keputusan pembelian pelanggan dipengaruhi oleh persepsi, motivasi, pembelajaran, sikap dan keyakinan. Persepsi dipantulkan pada bagaimana pelanggan memilih, mengatur, dan menginterpretasikan informasi untuk membentuk pengetahuan. Motivasi tercermin dari keinginan pelanggan untuk memenuhi kebutuhan mereka sendiri.

Menurut Hoffman and Fodor (2010), e-commerce dapat berjalan dengan baik apabila dijalankan berdasarkan prinsip 4C, yaitu: connection (koneksi), creation (penciptaan), consumption (konsumsi) dan control (pengendalian). Prinsip-prinsip ini dapat memotivasi konsumen yang mengarah pada return of investment (ROI) perusahaan, yang diukur dengan partisipasi aktif seperti feedback atau review konsumen, dan share atau merekomendasikan kepada pengguna lain.

Telah disebutkan di atas, bahwa teknologi saat ini memungkinkan kita untuk melakukan pemasaran apapun dengan bantuan internet. Oleh karena itu, dunia mengakui konsep baru aktivitas bisnis, yaitu dengan cara online. Salah satu keuntungan dalam menggunakan sumber internet untuk berhubungan dengan pelanggan adalah pengiriman data yang cepat dan informasi antara orang yang terlibat (Kozinets et al., 2010).

Enam dimensi keberhasilan sistem informasi menurut DeLone \& McLean (2004) yang dapat diterapkan juga pada lingkungan e-commerce adalah sebagai berikut:

1. Kualitas Sistem dalam lingkungan Internet. Dimana karakteristik sistem ecommerce dapat diukur sesuai kegunaan, ketersediaan, kehandalan, kemampuan beradaptasi, dan waktu respon (misalnya, waktu download dan proses data).

2. Kualitas Informasi dalam menangkap isu konten e-commerce. Jaringan konten harus dipersonalisasi, lengkap, relevan, mudah dimengerti, dan aman jika calon pembeli atau pemasok memulai transaksi melalui internet.

3. Kualitas layanan. Dukungan keseluruhan disampaikan oleh penyedia layanan, terlepas dari apakah dukungan tersebut disampaikan oleh departemen system informasi atau unit organisasi baru atau mungkin secara outsourcing ke penyedia layanan internet.

4. Penggunaan. Diukur dari kunjungan ke situs web dan navigasi dalam situs tersebut untuk pencarian informasi dan pelaksanaan transaksi.

5. Kepuasan Pengguna. Ini merupakan cara penting untuk mengukur pendapat pelanggan dalam sistem e-commerce dan harus mencakup seluruh yang pengalaman pelanggan dalam siklus pembelian, pembayaran, sampai penerimaan produk maupun layanan.

6. Manfaat. Ini juga penting, karena penting untuk menangkap keseimbangan dampak positif dan negatif dari e-commerce pada pelanggan, pemasok, karyawan, organisasi, pasar, industri, ekonomi, dan bahkan masyarakat secara keseluruhan

Menurut Schradi (2009), ada dua cara untuk melakukan pemasaran online, yaitu pasif dan aktif. Menggunakan pemasaran online pasif berarti sebuah perusahaan membangun sebuah website yang menyediakan informasi kepada pelanggan tanpa melakukan kegiatan yang signifikan untuk menjangkau pelanggan. Sedangkan pemasaran online aktif melakukan sebaliknya, yaitu perusahaan berusaha untuk mencapai pembeli potensial di internet. Dengan mengambil keuntungan dari teknologi internet, perusahaan memiliki kemudahan dalam mempromosikan dan menyampaikan informasi tentang merk mereka (Kaplan \& Haenlein, 2012).

Pertumbuhan belanja online juga telah mempengaruhi struktur industri. Ecommerce telah merevolusi cara bertransaksi berbagai bisnis, seperti toko buku dan agen perjalanan. Umumnya, perusahaan besar dapat menggunakan skala ekonomi dan menawarkan harga yang lebih rendah. Individu atau pelaku bisnis yang terlibat dalam e-commerce, baik itu pembeli maupun penjual mengandalkan teknologi berbasis internet untuk melaksanakan transaksi mereka. E-commerce memiliki kemampuan untuk memungkinkan transaksi kapan saja dan di mana saja. Kekuatan e-commerce memungkinkan hambatan-hambatan 
geofisika menghilang (Blut et al., 2015). Kim et al., (2011) berpendapat bahwa konteks budaya membentuk penggunaan teknologi komunikasi dan pola penggunaan situs jaringan sosial. Mereka berpendapat bahwa aviditas media bisa jadi berbeda di negara-negara yang berbeda, sesuai dengan karakteristik budaya negara masing-masing. Masyarakat kolektif, misalnya di negara.

Hasil analisis data menunjukkan pelaku wirausaha muda mahasiswa IAIN Kudus, lebih di dominasi oleh mahasiswa perempuan dibandingkan laki-laki dengan presentasi $83,6 \%$ dan sisanya 16,4 pelaku wirausaha mahasiswa laki-laki.

Tabel 1. Distribusi Pelaku E-Commerce pada Mahasiswa

\begin{tabular}{|c|c|c|c|}
\hline NO & PELAKU USAHA & JUMLAH & PRESENTASE \\
\hline $\mathbf{1}$ & Perempuan & 28 & 83,6 \\
\hline $\mathbf{2}$ & Laki-Laki & 140 & 16,4 \\
\hline & JUMLAH & 168 & 100 \\
\hline
\end{tabular}

Sumber: Data primer diolah, 2018

Hal ini dikarenakan secara demografis, struktur penduduk Indonesia yang menunjukkan dominasi yang lebih dominan jumlah perempuan dibandingkan dengan lakilaki. Karena perempuan di anggap lebih bersifat multitasking dibandingkan dengan lakilaki. Mahasiswa perempuan dianggap mampu menajemen waktu yaitu mengikuti perkuliahan dan juga menjalankan bisnisnya secara bersama-sama daripada mahasiswa laki-laki. Hal ini sejalan dengan tulisan Herbert (dalam Santrock,2002) perbedaan kritis antara laki-laki dan perempuan adalah, perempuan mampu merasakan dan mengartikulasikan persaan mereka. Berbeda dengan laki-laki, karena pengkondisian maskulinitas mereka tidak dapat mersakan dan mengartikulasikan persaan mereka sehingga menjadikan mereka pekerja yang produktif dan efektif.

Jika dilihat dari minat mahasiswa dalam bisnis melalui e commerce 84,4\% mahasiswa berminat sebagai pelaku dan $15,6 \%$ sebagai konsumen dalam e-commerce adalah sebagai berikut:

Tabel 2. Ketertarikan mahasiswa dalam bisnis E-Commerce

\begin{tabular}{|c|l|r|r|}
\hline No & Keterangan & Jumlah & Presentase \\
\hline $\mathbf{1}$ & Berminat & 142 & $84,4 \%$ \\
\hline $\mathbf{2}$ & Tidak berminat & 26 & $15,6 \%$ \\
\hline & Jumlah & 168 & $100,0 \%$ \\
\hline
\end{tabular}

Sumber: data primer diolah, 2018

Berdasarkan pemasaran yang dilakukan sebagian besar wirausaha muda lebih banyak melakukan pemasaran dalam waktu yang berbeda-beda, rata-rata mahasiswa melakukan pemasaran kurang dari 5 kali dalam sehari atau sebesar 35, 3\% hal ini dikarenakan keterbatasan waktu yang dimiliki mahasiswa. 


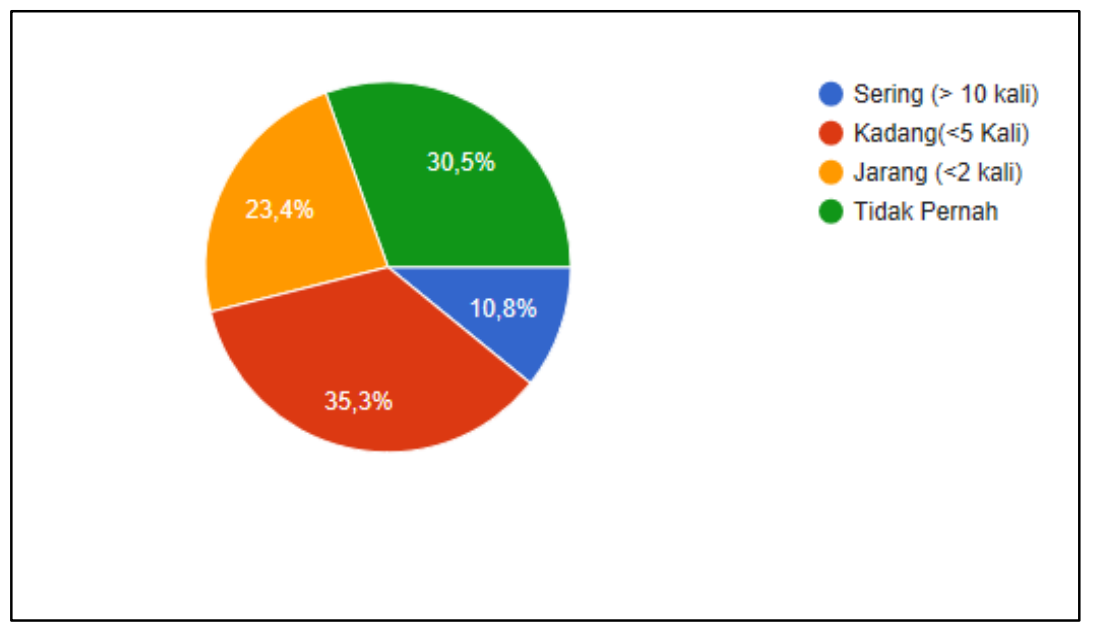

Sumber: Data Primer diolah, 2018

Melihat hasil penelitian yang demikian dapat disimpulkan bahwa penerapannya pada kewirausahaan terutama yang dikelola oleh wirausaha muda masih sangat minim. Terdapat berbagai kendala yang dihadapi pelaku antara lain minimnya pengetahuan yang dimiliki, keterbatasan waktu, minimnya kesadaran pelaku. Menurut Guth \& Ginsberg (1990) perilaku kewirausahaan merupakan perilaku untuk menjalankan gagasan, meningkatkan daya saing, menyesuaikan organisasi terhadap perubahan lingkungan serta upaya mencapai kinerja yang lebih baik. Dalam hal ini perilaku kewirausahaan akan dikaitkan dengan faktor inovasi (innovation), kemampuan yang proaktif (proactiveness) dan keberanian mengambil risiko (risk taking). Hal ini di perkuat dengan pendapat dari Zahra (1993) bahwa perilaku berwirausaha dapat didefinisikan sebagai sekumpulan aktivitas individu dalam hal inovasi, pencarian usaha baru (venturing), dan pembaharuan strategik (strategic renewal). Lebih lanjut Zahra (1993) menjelaskan perilaku kewirausahaan merupakan aktivitas dengan menggunakan imajinasi, keberanian, intelegensi/kecerdasan, kepemimpinan, ketekunan, dan kebulatan tekad untuk mengejar kekayaan, kekuasaan dan posisi.

Biasanya pemasaran yang dilakukan dalam wirausaha muda mahasiswa IAIN Kudus melalui via Whatsapp, Instagram, Facebook dan media social lainnya adalah:

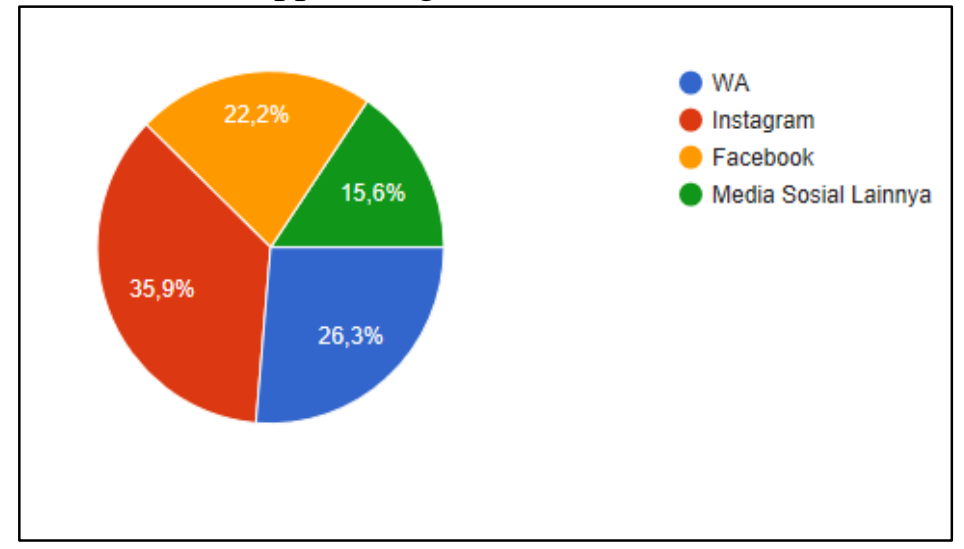

Sumber: Data Primer diolah, 2018.

Berdasarkan data tersebut spirit wirausahaan yang dikelola oleh wirausaha muda sebagaian besar memilih pemasaran melalui Instagram sebesar 35,9\% dan posisi kedua pemasaran yang banyak diminati adalah via Whatsapp sebesar 26, $3 \%$ hal ini membuktikan bahwa jiwa wirausahaan mahasiswa dalam melakukan pemasaran sudah sangat baik dalam memanfaatkan media social dalam mengembangkan usahanya dan memperluas pasar. Hal ini sejalan dengan mengambil keuntungan dari teknologi internet, perusahaan memiliki 
kemudahan dalam mempromosikan dan menyampaikan informasi tentang merk mereka (Kaplan \& Haenlein, 2012)

Keuntungan dalam bisnis melalui E-Commerce yang didapatkan oleh wirausaha muda adalah sebagai berikut:

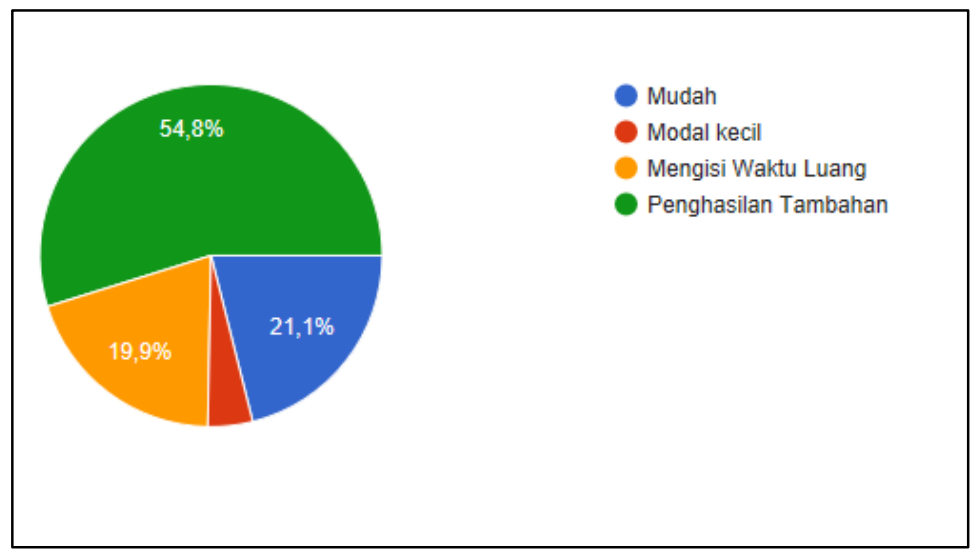

Sumber: Data Primer diolah, 2018.

Dari data tersebut menunjukkan bahwa melakukan e-commerce 54,8\% motivasinya adalah memperoleh penghasilan tambahan. Motivasi kedua dalam melakukkan e-commerce $21,1 \%$ adalah kemudahan dalam berbisnis yang didapatkan. Selain itu motivasi lain adalah memanfaatkan waktu luang dalam bisnis sehingga menghasilkan sesuatu nilai ekonomi. Motivasi lain dalam bisnis e-commerce adalah hanya memebutuhkan modal kecil dalam usaha karana biasanya mahasiswa hanya melakukan reseller dari produsen. Selain keuntungankeuntungan yang didapatkan dalam pemanfaatan e-commerce, adapula hal negatif yang dirasakan sebagai resiko yang didapatkan yaitu biaya investasi pada penggunaan IT yang dirasakan masih sangat mahal, serta resiko lain terhadap tindakan penipuan dan kecurangan (misal: barang tiruan, transaksi palsu, dll)

\section{E. KESIMPULAN}

Berdasarkan penelitian yang sudah dilakukan dapat disimpulkan mahasiwa memiliki Realiasasi Spirit Entreprenuership yang tinggi. Hal ini di buktikan banyak mahasiswa yang telah melakukkan kewirausahaan melalui e-commerce. Dan dengan penerapan e-commerce dapat memperluas pemasaran, memberikan efisiensi bisnis, biaya operasional terkendali, tidak terbatas ruang dan waktu, dan dapat meningkatkan penghasilan.

Berdasarkan pembahasan yang telah dilakukan dapat disimpulkan bahwa pelaksanaan pendidikan kewirausahaan di perguruan tinggi perlu terus diberikan agar terjadi perubahan mindset pada mahasiswa yang selama ini hanya berminat sebagai pencari kerja (job seeker) menjadi mahasiswa yang siap menciptakan lapangan pekerjaan. Selain itu, pemberian pendidikan kewirausahaan diberikan dalam rangka membekali mahasiswa agar memiliki keterampilan hidup (live skill) dan kemampuan beradaptasi serta kemampuan bersosialisasi (soft skill) terhadap lingkungan kerja. Perubahan perilaku yang diharapakan dengan adanya pendidikan kewirausahaan adalah mahasiswa memiliki motif berprestasi, pantang menyerah, keberanian mengambil risiko, kreatif dan inovatif. Untuk pelaksanaan pendidikan kewirausahaan di kampus, tidak hanya memberikan bekal secara teori tetapi juga memberikan contoh praktek kewirausahaan yang dapat memberikan gambaran nyata tentang kewirausahaan. Selain itu, untuk mencapai terbentuknya perilaku kewirausahaan pada mahasiswa maka secara praktis pengembangan perilaku kewirausahaan pada mahasiswa dapat melalui pelatihan-pelatihan kewirausahaan. 


\section{DAFTAR PUSTAKA}

Ajzen, I (2006). The theory of planned behavior. Retrived Desember, 19,2015 from: 5

Ajzen, I and Fisbein, M. 1980. Understanding Attitudes and Predicting Social Behabior. Prentice-Hall, Englewood Cliffs. NJ.

Blut, Markus and Frennea, Carly and Mittal, Vikas and Mothersbaugh, David L. (2015): How Procedural, Financial and Relational Switching Costs Affect Customer Satisfaction, Repurchase Intentions, and Repurchase Behavior: A Meta-Analysis. International Journal of Research in Marketing.

Delone, William H., and Ephraim R. Mclean. "Measuring e-commerce success: Applying the DeLone \& McLean information systems success model."International Journal of Electronic Commerce 9.1 (2004): 31-47.

Guth, W. and Ginsberg, A. 1990. Guest Editor's Introduction: Corporate Entrepreneurship. Strategic Management Journal, Vol. 11 (summer special issue), pp. 5-15

Hisrich, Robert D.; Peters, Michael P dan Shepherd Dean A. 2013. Entrepreneurship, ed. 9. McGraw-Hill Education.

Hoffman, Donna L., and Marek Fodor. "Can you measure the ROI of your social media marketing." MIT Sloan Management Review 52.1 (2010): 41-49.

Indarti dan Rostiani, 2008 : Intensi Kewirausahaan Mahasiswa : Studi Perbandingan Antara

Kaplan, A.M and Michael Haenlein (2012): Users of the world, unite! The challenges and opportunities of Social Media, Business Horizons (2010) 53, p. 59-68.

Kim, Yoojung, Dongyoung Sohn, and Sejung Marina Choi (2011): "Cultural difference in motivations for using social network sites: A comparative study of American and Korean college students." Computers in Human Behavior 27.1 (2011): 365-372.

Kozinets, Robert V., et al. "Networked narratives: Understanding word-of-mouth marketing in online communities." Journal of marketing 74.2 (2010): 71-89.

Kotler P. 2000. Marketing Management: The Millenium Edition. Prestice Hall.

Katz, J., dan W. Gartner, 1988. "Properties of emerging organizations".Academy of Management Review

Linan, F. (2004). Intention-based models of entrepreneurship education. Piccolla

Mandagi, M. (2014). Strategi perguruan tinggi dalam mewujudkan entrepreneurial campus. Jurnal Kajian Pendidikan. ISSN 2088-1290. 257 - 258 
McClelland, D., 1961. The Achieving Society, Princeton, New Jersey: Nostrand. 1971. The Achievement Motive in Economic Growth, in: P. Kilby (ed.)

Sinha, T. N., 1996. "Human Factors In Entrepreneurship Effectiveness". Journal of Entrepreneurshi

Suryana. (2009). Kewirausahaan pedoman praktis: kiat dan proses menjuju sukses. Jakarta: Salemba Empat

Susilaningsih. (2015). Pendidikan kewirausahaan di perguruan tinggi: pentingkah untuk semua profesi?. Prosiding Seminar Nasional, 850-858.

Schradi, B. (2009): Online Marketing Internet Lexikon [online] Available from: http://www.symweb.de/glossar/online-marketing__169.htm [Accessed 23 March 2018].

Zahra, S. (1993). A Conceptual Model of Entrepreneurship as Firm Behavior: A Critique and Extension, ET \& P, 5-21.

(www.kelembagaan.dikti.go.id, 2009) 